\title{
What Do Entrance Examinations Say About EFL Outcomes at Universities?
}

\section{Giancarla Unser-Schutz \\ Rissho University}

\section{Reference Data:}

Unser-Schutz, G. (2020). What do entrance examinations say about EFL outcomes at universities? In P. Clements, A. Krause, \& R. Gentry (Eds.), Teacher efficacy, learner agency. Tokyo: JALT. https://doi.org/10.37546/JALTPCP2019-64

Many Japanese universities now accept a large percentage of students who have not taken traditional entrance examinations, most commonly through recommendation. Although this can foster diversity, it can also lead to proficiency gaps amongst students in English courses. A longitudinal study was conducted of students through 2 years of required EFL courses using TOEIC results from the $1 \mathrm{st}$ and 2 nd years, and matched surveys on attitudes towards English from the beginning, middle and end of 2 years of English courses. Students who gained admission through traditional entrance examinations tended to score higher on the TOEIC, but the results for the surveys were similar for both groups of students. Although the admissions process may not capture students' attitudes towards English, it may be an indicator of post-matriculation performance, which will have increasing importance as university admissions processes change. 近年では、推薦入試等で定員を確保する傾向が、私立大学を中心に強まっている。この变化に伴い、学生の総合的な評価 が可能になったという肯定的な側面がある一方、能力的格差が広がっているという指摘も見られる。本研究では、入試形態別 に1・2年次のTOEIC 結果及び入学時・2年次開始・2年次末に実施された英語学習に対する態度調查の結果比較を行った。英 され、推薦入試の学生のフォローが必要であることが示された。大学入学制度が大きく変わろうとしている今日、この問題がま すます深刻になっていくことも最後に指摘する。

${ }^{\nabla}$ raditionally, most students enrolling at Japanese universities gain placement through competitive examinations. However, over the last 20 years more universities have begun accepting students through alternative admissions channels. The development of new types of examinations has partially been to make up for decreases in numbers of students as the population declines (Mori, 2002). Most of these alternative channels differ in how they weigh academic achievements and tend to evaluate students holistically. These changes in the admissions system have led to changes in student populations. They may also be reflected in student performance at universities.

The most common alternative admissions channel is suisen nyūshi ("recommendation entrance examinations"), which includes shiteikö-suisen ("designated school recommendations"), where students recommended by their high schools are awarded placements through formal agreements with universities (Table 1). There are also recommendation-adjacent tests, such as the $A O$-nyūshi ("admissions-office examinations"), where students participate in workshops and presentations in lieu of traditional academic examinations. These examinations differ greatly from ippan-nyūshi ("general academic examinations"), the traditional academic examinations held by the universities themselves, which usually consist of between three and nine subjects, as well as sentā riyō ("use of the Center test"), whereby students gain admission based on scores on the National Center Test for University Admissions. For clarity, alternative admissions channels will be referred to as recommendation examinations below, and students who gain admission through these examinations as recommendation students.

One benefit of these recommendation examinations is that because students are not given a fact-based, memorization-oriented, traditional academic examination, universities are free to use other methods to consider which candidates are a good match for their school. This can foster diversity through the holistic evaluation of students (Mori, 2002). Students who spent most of high school involved in non-academic activities, such as athletes and musicians, can show how they can contribute to the school. Likewise, students who might not perform well on traditional examinations, but who would otherwise make worthy candidates, such as those prone to anxiety in testing situations and those unable to attend the costly cram schools often necessary to do well on entrance examinations, are also given opportunities to shine. 
From an administrative point of view, there are also many pragmatic reasons to support these alternative channels. As traditional examinations are meant to test the culmination of high school study, they must be conducted at the end of high school. Consequently, they are usually held between January and March. On the other hand recommendation examinations do not have this restriction, and can be held many times throughout the year. This gives universities a longer window of time in which to conduct examinations, and potentially more opportunities for them to attract students and fill their places. Recommendation examinations also allow universities to draw from a wider pool of potential students, including those who might not have considered university study.

However, recommendation examinations are not without controversy. They are often associated with a proficiency gap amongst students (Kochiyama, 2010; Metoki, 2014), and because they do not prioritize academic achievement, weaker students may actively pursue recommendation. Accepting a diversity of students often means accepting a diversity of abilities, but gaps in students' abilities may also be due to differences in how students pursue their studies in the months prior to matriculation. Most recommendation examinations are held between October and November, but high school graduation is in mid-March. Consequently, recommendation students know where they will be going several months prior to graduation and do not need to study as intensely as is necessary for success on traditional entrance examinations. In comparison, the latest round of entrance examinations is in March. Incoming students at some universities are made up of both students who were accepted in October of their final year of high school and no longer had any extrinsic motivation to continue studying, as well as students who continued studying intensely until March.

In light of this, many universities now require pre-matriculation courses for recommendation students; by $2014,70 \%$ of universities reported having programs to ensure that recommendation students continue studying, such as training camps and lecture courses (Higuchi, 2014). These gaps in student abilities are often said to be pronounced in English classes (Kochiyama, 2010; Metoki, 2014) because English is often less prioritized within the recommendation system. Although some recommendation examinations include English components, they are usually not as intense as the 60 - to 150-minute tests typical of traditional examinations and the National Center Test for University Admissions. As such, how students gain admission to university may strongly impact how they perform in their post-matriculation English studies, and universities

Table 1. Common Types of Entrance Exams

\begin{tabular}{|c|c|c|c|c|c|c|c|c|c|}
\hline & & & \multirow[b]{2}{*}{$\begin{array}{l}\text { General period } \\
\text { conducted }\end{array}$} & \multirow[b]{2}{*}{ Recommender } & \multirow{2}{*}{$\begin{array}{c}\text { Agreement between } \\
\text { high school and } \\
\text { university }\end{array}$} & \multicolumn{4}{|c|}{ Importance of } \\
\hline \multicolumn{3}{|c|}{ Type of test } & & & & Written test & Grades & Interview & $\begin{array}{c}\text { Presentations } \\
\text { /workshops }\end{array}$ \\
\hline \multirow[t]{2}{*}{$\begin{array}{l}\text { Traditional } \\
\text { channels }\end{array}$} & Ippan-nyūshi & $\begin{array}{l}\text { General academic } \\
\text { test }\end{array}$ & $\begin{array}{l}\text { February to } \\
\text { March }\end{array}$ & None & No & $\begin{array}{l}\text { Highly } \\
\text { competitive }\end{array}$ & None & None & None \\
\hline & Sentā-riyō & $\begin{array}{l}\text { Use of the Center } \\
\text { Test }\end{array}$ & January & None & No & $\begin{array}{l}\text { Highly } \\
\text { competitive }\end{array}$ & None & None & None \\
\hline \multirow[t]{3}{*}{$\begin{array}{l}\text { Alternative } \\
\text { channels }\end{array}$} & Shiteikō-suisen & $\begin{array}{l}\text { Designated } \\
\text { school } \\
\text { recommendation }\end{array}$ & $\begin{array}{l}\text { October to } \\
\text { November }\end{array}$ & High school & Yes & $\begin{array}{l}\text { None/largely } \\
\text { cursory }\end{array}$ & Largely cursory & $\begin{array}{l}\text { Largely } \\
\text { cursory }\end{array}$ & None \\
\hline & Kōbō-suisen & $\begin{array}{l}\text { Open/self- } \\
\text { recommendation }\end{array}$ & $\begin{array}{l}\text { October to } \\
\text { November }\end{array}$ & $\begin{array}{l}\text { Respected } \\
\text { member of } \\
\text { community }\end{array}$ & No & $\begin{array}{l}\text { Moderately } \\
\text { competitive }\end{array}$ & $\begin{array}{l}\text { Moderately } \\
\text { competitive }\end{array}$ & $\begin{array}{l}\text { Moderately } \\
\text { competitive }\end{array}$ & None \\
\hline & AO-nyūshi & $\begin{array}{l}\text { Admission's office } \\
\text { test }\end{array}$ & $\begin{array}{l}\text { August to } \\
\text { March }\end{array}$ & None & No & $\begin{array}{l}\text { Moderately } \\
\text { competitive }\end{array}$ & $\begin{array}{l}\text { Moderately } \\
\text { competitive }\end{array}$ & $\begin{array}{l}\text { Moderately } \\
\text { competitive }\end{array}$ & $\begin{array}{l}\text { Moderately } \\
\text { competitive }\end{array}$ \\
\hline
\end{tabular}


must fully deal with the consequences. Are students able to overcome these gaps? If not, what do universities need to do to fully support all students?

\section{Methodology}

This study followed students through 2 years of required EFL courses in a non-Englishmajor faculty at a small private university in Tokyo (Faculty Y in University X). Faculty $\mathrm{Y}$ requires students to take three required courses (two grammar-oriented year-long reading and writing courses in their first year and a conversation-oriented year-long speaking course in their second). However, English is not a central component of the curriculum, accounting for only 6 of the 124 credits required for graduation. Students who are interested in studying English intensely are unlikely to select Faculty Y. Nonetheless, English is one of the three subjects students taking the traditional examinations must select, meaning it is a large part of how students are competitively chosen. In comparison, although high school English grades and questions on English at the interview are given consideration, there is no formal English test within the recommendation examinations. As such, Faculty $Y$ is a particularly good case for examining the differences between postmatriculation outcomes by examination method.

Students in the faculty were tracked using two sources of data: TOEIC scores from the beginning of their 1st and 2nd years, and three matched surveys on their attitudes towards English at the beginning, middle, and end of their 2 years of English courses. TOEIC scores were used to track performance as all students at the university took them. However, TOEIC may not always be the most appropriate method for evaluating students, as curricula are not always designed around raising TOEIC scores. As a result, positive performance in university classes may not always correlate directly with rises in TOEIC scores. Effective curricula should also help students grow in ways that the TOEIC cannot evaluate, such as pragmatic skills and interest in studying English.

Given these limitations, Faculty Y began conducting surveys on students' attitudes towards English study in 2016 to gain data on how effective the faculty's curriculum has been at fostering interest in English. Students take the same survey three times over the course of their compulsory English study: (a) in April at the beginning of their 1st year, (b) in April at the beginning of their 2nd year, and (c) in January at the end of their required English classes. This is done to obtain baseline data on attitudes to English prior to matriculation and how those attitudes change over time.

The survey consists of 10 Likert-scale items on students' attitudes towards and experience with English; one background question; and one free-answer question on English study. The survey is conducted in Japanese to encourage student participation;

Table 2 shows the translated questions, with the originals in the Appendix. The questions on how much students were looking forward to English, and their interest in other areas of English were included because positive attitudes and experience with foreign cultures had been found to influence attitudes towards English study (Munezane, 2013). Intensity of study was included because more than half of recommendation students report spending an hour or less a day studying in their final year of high school (Benesse, 2012), which may affect their interest in English study. Student data were initially matched using student numbers; this information was anonymized post-collection and removed from the matched data used here.

The aims and goals of the surveys were explained at each session, and students were asked to give their consent to participate. Those who did not were given the option to opt out at any point. Neither the TOEIC tests nor the surveys were used in any part of evaluating students. Note that at present, the TOEIC test is not used as a placement test within the faculty; classes are instead determined by student number, which are assigned in the order that matriculation paperwork is received. Since the recommendation students fill out the paperwork earlier, English classes are currently largely segregated by admission method. The classes themselves all use the same textbooks and are not divided by level. The project and surveys were developed as a faculty-led initiative.

Table 2. Questions in Survey Question/statement Answer form

1 Have you been abroad?

2 How intensely did you study English in the previous year?

3 How satisfied were you with your English classes in the previous year?

4 How much are you looking forward to studying English in the upcoming year?

5 Do you like learning English?

6 I am interested in studying abroad.

$7 \quad \mathrm{I}$ am interested in using English at work.
Yes / No

Not at all/1 -2 -3 - $4-5 /$ Very much

Not at all/1 -2 -3 - 4-5/Very much

Not at all/1 -2 -3 - 4 -5/Very much

Not at all/1 -2 -3 - 4 -5/Very much

Not at all/1 -2 -3-4/Very much

Not at all/1 -2 -3-4/Very much 
Unser-Schutz: What Do Entrance Examinations Say About EFL Outcomes at Universities?

\begin{tabular}{lll}
\hline$\#$ & \multicolumn{1}{c}{ Question/statement } & \multicolumn{1}{c}{ Answer form } \\
\hline 8 & $\begin{array}{l}\text { I am interested in English-related } \\
\text { qualifications. }\end{array}$ & Not at all/1 -2 -3-4/Very much \\
9 & I am interested in foreign cultures. & Not at all/1 $-2-3-4 /$ Very much \\
10 & I am interested in making foreign friends. & Not at all/1 $-2-3-4 /$ Very much \\
11 & I am interested in English. & Not at all/1 $-2-3-4 /$ Very much \\
12 & $\begin{array}{l}\text { Please tell us here if you have any other } \\
\text { desires for English education or things you } \\
\text { want to tell us about English education. }\end{array}$ & Free form \\
\hline
\end{tabular}

Currently, data has been collected for the incoming classes of 2016 and 2017, garnering a total of 188 and 142 valid responses from students who gained admission via traditional and recommendation examinations, respectively (Table 3). Although the TOEIC and survey was administered to all students, in this article valid data means any student data that is complete for all five phases of the study: The 1st- and 2nd-year TOEIC scores and the three surveys over the 1st and 2 nd years. Data were tagged by how students gained admission, which was limited to traditional examinations and recommendation examinations. Data from the ryūgakusei-nyūshi ("international student examination") and the shakaijin-nyūshi ("older student examination") were exempted. This is because there were fewer than five such students, and the examinations are distinctly different. The valid responses reported here account for approximately $60 \%$ of the student body for the two graduating classes included; the remaining $40 \%$ were excluded as those students did not participate in all five phases. There were disproportionately more responses from female students, but this is consistent for Faculty $\mathrm{Y}$ in general, where female students usually make up between $60 \%$ and $70 \%$ of the student body. There was also a somewhat larger number of responses from students who had gained admission through traditional examinations. This is typical as the faculty sets aside a larger number of places for students who take traditional examinations.
Table 3. Sample Details

\begin{tabular}{|c|c|c|c|c|c|c|c|}
\hline \multirow{2}{*}{$\begin{array}{l}\text { Incoming } \\
\text { class }\end{array}$} & \multirow{2}{*}{$\begin{array}{l}\text { Entrance } \\
\text { examination type }\end{array}$} & \multicolumn{2}{|c|}{ Female } & \multicolumn{2}{|c|}{ Male } & \multicolumn{2}{|c|}{ Total } \\
\hline & & $\#$ & $\%$ SB & \# & $\%$ SB & $\#$ & $\% \mathrm{SB}$ \\
\hline \multirow[t]{3}{*}{2016} & Recommendation & 55 & $56.12 \%$ & 16 & $44.44 \%$ & 71 & $52.99 \%$ \\
\hline & Traditional & 63 & $61.76 \%$ & 28 & $56.00 \%$ & 91 & $59.87 \%$ \\
\hline & Total & 118 & $59.00 \%$ & 44 & $51.16 \%$ & 162 & $56.64 \%$ \\
\hline \multirow[t]{3}{*}{2017} & Recommendation & 60 & $58.25 \%$ & 11 & $50.00 \%$ & 71 & $56.80 \%$ \\
\hline & Traditional & 60 & $63.83 \%$ & 37 & $64.91 \%$ & 97 & $64.24 \%$ \\
\hline & Total & 120 & $60.91 \%$ & 48 & $60.76 \%$ & 168 & $60.87 \%$ \\
\hline \multirow[t]{3}{*}{ All } & Recommendation & 115 & $57.21 \%$ & 27 & $46.55 \%$ & 142 & $54.83 \%$ \\
\hline & Traditional & 123 & $62.76 \%$ & 65 & $60.75 \%$ & 188 & $62.05 \%$ \\
\hline & All & 238 & $59.95 \%$ & 92 & $55.76 \%$ & 330 & $58.72 \%$ \\
\hline
\end{tabular}

Notes. \# = Number in sample, \% SB = Percentage of the student body, within that group.

Statistical analyses were conducted using three-way analyses of variation (ANOVA) to compare students' scores on TOEIC and the three surveys to see how students changed over their course of their study. Data were compared between those who entered through traditional examinations and those who entered through recommendation examinations. Scores were also compared between the incoming class of 2016 and 2017 to determine if trends observed between the two entrance examination groups were consistent. For the purposes of this paper, only the main questions from the survey (2 to 5 in Table 2) have been analyzed.

\section{Results}

\section{TOEIC Scores}

According to a three-way mixed ANOVA analysis, traditional examination students scored significantly higher on the TOEIC test than recommendation examination students, with traditional students averaging 360.37 and 352.42 for the 1st- and 2ndyear tests (main effect for test type, $F[1,326]=74.58, p<.01^{* * *}$; Table 4 ; Appendix, 
Unser-Schutz: What Do Entrance Examinations Say About EFL Outcomes at Universities?

Table 10). No significant differences were found by graduating class $(F[1,326]=0.41$, $n s)$, nor were there any significant differences for any group between the 1 st and 2 nd years $(F[1,326]=1.93, n s)$.

Table 4. Results of the TOEIC Examinations

\begin{tabular}{llccccc}
\hline \multirow{2}{*}{$\begin{array}{l}\text { Incoming } \\
\text { class of }\end{array}$} & Exam type & $M$ & $S D$ & $M$ & $S D$ & $N$ \\
\hline \multirow{2}{2016}{} & Recommendation & 286.55 & 74.52 & 284.79 & 73.72 & 71 \\
& Traditional & 368.41 & 86.01 & 355.27 & 98.42 & 91 \\
& Overall & 332.53 & 90.77 & 324.38 & 95.11 & 162 \\
& & & & & & \\
2017 & Recommendation & 288.17 & 68.96 & 283.38 & 68.68 & 71 \\
& Traditional & 352.84 & 72.34 & 349.74 & 97.26 & 97 \\
& Overall & 325.51 & 77.79 & 321.70 & 92.36 & 168 \\
\hline
\end{tabular}

\section{Attitude Surveys}

Self-Reported Intensity of Study

When asked how intensely they studied English in the previous year(s), no differences were found for the main effect of graduating year using a three-way mixed ANOVA ( $F[1$, $324]=1.21, n s)$. Significant differences were not found between entrance methods $(F[1$, $324]=0.20, n s)$. The main effect of year in school was significant $(F[2,648]=37.39, p$ $<.01^{* * *}$ ) (Table 5; Appendix, Table 11). The interaction effect of graduating class and entrance method, entrance method and year in course, and graduating class and year in course were all marginally significant $(F[1,324]=3.04, p<.1+; F[2,648]=3.02, p<.1+$; $F[2,648]=2.42, p<.1+$, respectively). Post hoc comparisons using Bonferroni corrections showed that students who gained admission through traditional examinations reported studying equally intensely during high school and in their 2 nd year at university $\left(\alpha^{\prime}=\right.$ $0.0167,0.5 / 3, p<.05 *)$. However, these students reported studying less in their 1 st year at university. Those who gained admission through recommendation examinations reported studying the most during their 2 nd year, followed by high school and their 1st year at university $\left(\alpha^{\prime}=0.0167,0.5 / 3, p<.05 *\right)$.
Table 5. Students' Self-Reported Intensity of Study

\begin{tabular}{llccccccc}
\hline \multirow{2}{*}{$\begin{array}{l}\text { lncoming } \\
\text { class of }\end{array}$} & Exam type & \multicolumn{2}{c}{$\begin{array}{c}\text { Beginning of } \\
1^{\text {st }} \text { year }\end{array}$} & \multicolumn{2}{c}{$\begin{array}{c}\text { Beginning of } \\
2^{\text {nd }} \text { year }\end{array}$} & \multicolumn{2}{c}{ End of 2 ${ }^{\text {nd }}$ year } & \\
\cline { 2 - 7 } 2016 & $M$ & $S D$ & $M$ & $S D$ & $M$ & $S D$ & $N$ \\
\hline & Recommendation & 3.39 & 0.99 & 2.97 & 1.11 & 3.94 & 0.80 & 71 \\
& Traditional & 3.54 & 1.05 & 3.27 & 1.06 & 3.81 & 0.95 & 90 \\
& Overall & 3.48 & 1.02 & 3.14 & 1.09 & 3.87 & 0.89 & 161 \\
& & & & & & & & \\
& Recommendation & 3.45 & 0.92 & 3.23 & 1.00 & 3.79 & 0.84 & 71 \\
& Traditional & 3.36 & 1.11 & 3.11 & 1.14 & 3.46 & 1.07 & 96 \\
& Overall & 3.40 & 1.03 & 3.16 & 1.08 & 3.60 & 0.99 & 167 \\
\hline
\end{tabular}

\section{Satisfaction With English Classes}

When asked how satisfied they were with their English classes in the previous year(s), students reported an average below or close to 3 points (neither satisfied nor dissatisfied) over all three surveys. No differences were found between how students gained admission using a three-way mixed ANOVA $(F[1,325]=0.27, n s)$. The main effect by graduating class was marginally significant $(F[1,325]=2.83, p<.1+$; Table 6 ; Appendix, Table 12), but the main effect of their year in school was significant $(F[2,650]$ $=154.28, p<.01 * *)$. The interaction effect between the graduating class and how they gained admission was also significant $\left(F[1,325]=5.36, p<.05^{*}\right)$, with students from the incoming class of 2017 who gained admission through traditional examinations showing the least satisfaction overall $(F[1,325]=7.07, p<.01 * *)$. Post hoc comparisons using Bonferroni corrections showed that students reported the highest satisfaction at the end of their 2 nd year, and the lowest satisfaction at the beginning of their second year $\left(\alpha^{\prime}=\right.$ $0.0167,0.5 / 3, p<.05 *)$. 
Unser-Schutz: What Do Entrance Examinations Say About EFL Outcomes at Universities?

Table 6. Student Satisfaction With English Classes

\begin{tabular}{|c|c|c|c|c|c|c|c|c|}
\hline \multirow{2}{*}{$\begin{array}{l}\text { Incoming } \\
\text { class of }\end{array}$} & \multirow[b]{2}{*}{ Exam type } & \multicolumn{2}{|c|}{$\begin{array}{c}\text { Beginning of } \\
1^{\text {st }} \text { year }\end{array}$} & \multicolumn{2}{|c|}{$\begin{array}{c}\text { Beginning of } \\
2^{\text {nd }} \text { year }\end{array}$} & \multicolumn{2}{|c|}{ End of $2^{\text {nd }}$ year } & \multirow[b]{2}{*}{$N$} \\
\hline & & $M$ & $S D$ & $M$ & $S D$ & $M$ & $S D$ & \\
\hline \multirow[t]{3}{*}{2016} & Recommendation & 2.73 & 1.03 & 2.69 & 1.03 & 3.87 & 0.87 & 71 \\
\hline & Traditional & 3.04 & 1.02 & 2.78 & 1.14 & 3.89 & 1.01 & 91 \\
\hline & Overall & 2.91 & 1.04 & 2.74 & 1.09 & 3.88 & 0.95 & 162 \\
\hline \multirow[t]{3}{*}{2017} & Recommendation & 2.97 & 0.97 & 2.64 & 0.94 & 3.83 & 0.89 & 70 \\
\hline & Traditional & 2.67 & 1.05 & 2.43 & 1.05 & 3.68 & 1.02 & 97 \\
\hline & Overall & 2.80 & 1.03 & 2.52 & 1.01 & 3.74 & 0.97 & 167 \\
\hline
\end{tabular}

\section{Looking Forward to English Study}

When asked whether they were looking forward to studying English, students reported an average under 3 points (neither looking forward nor not looking forward) over all three surveys. No differences were found according to how students gained admission using a three-way mixed ANOVA $(F[1,324]=0.00, n s)$, nor by incoming class $(F[1,324]=$ $0.58, n s ;$ Table 7; Appendix, Table 13). The main effect by year in school was significant $(F[2,648]=12.64, p<.01 * *)$. The interaction between the graduating class and year in school was marginally significant $(F[2,648]=2.37, p<.1+)$. The interaction effect between year in school and how much students looked forward to studying English was significant for the class of $2017(F[2,648]=12.88, p<.01 * *)$, but post hoc comparisons using Bonferroni corrections indicated that these differences were not significant $\left(\alpha^{\prime}=\right.$ $0.0167,0.5 / 3, n s)$.
Table 7. Degree Students Looked Forward to Studying English

\begin{tabular}{llccccccc}
\hline \multirow{2}{*}{$\begin{array}{l}\text { Incoming } \\
\text { class of }\end{array}$} & Exam type & \multicolumn{2}{c}{$\begin{array}{c}\text { Beginning of } \\
1^{\text {st }} \text { year }\end{array}$} & \multicolumn{2}{c}{$\begin{array}{c}\text { Beginning of } \\
2^{\text {nd }} \text { year }\end{array}$} & \multicolumn{2}{c}{ End of $2^{\text {nd }}$ year } & \\
\cline { 2 - 7 } 2016 & $M$ & $S D$ & $M$ & $S D$ & $M$ & $S D$ & $N$ \\
\hline & Recommendation & 2.93 & 0.99 & 2.70 & 1.10 & 2.81 & 0.96 & 70 \\
& Traditional & 2.99 & 1.19 & 2.84 & 1.19 & 2.86 & 1.19 & 90 \\
& Overall & 2.96 & 1.11 & 2.78 & 1.15 & 2.84 & 1.09 & 160 \\
& & & & & & & & \\
& Recommendation & 3.07 & 1.24 & 2.68 & 1.15 & 2.72 & 1.14 & 71 \\
& Traditional & 3.02 & 1.07 & 2.55 & 1.06 & 2.64 & 0.97 & 97 \\
& Overall & 3.04 & 1.17 & 2.60 & 1.11 & 2.67 & 1.07 & 168 \\
\hline
\end{tabular}

Degree Students Liked Learning English

When asked how much they liked learning English, students reported an average under 3 points (neither like nor dislike learning English) over all three surveys. However, no differences were found between students who gained admission using a three-way mixed ANOVA $(F[1,324]=0.15, n s)$, nor by graduating class $(F[1,324]=0.03, n s$; Table 8; Appendix, Table 14). No significant interaction effects were found between the variables. The main effect of year in school was significant $(F[1,648]=8.99, p<.01 * *)$. Post hoc comparisons using Bonferroni corrections showed that students reported liking studying English more after their second year than after their first year, but there were no other significant differences $\left(\alpha^{\prime}=0.0167,0.5 / 3, p<.05 *\right)$. 
Table 8. Degree Students Liked Learning English

\begin{tabular}{llccccccc}
\hline \multirow{2}{*}{$\begin{array}{l}\text { Incoming } \\
\text { class of }\end{array}$} & Exam type & \multicolumn{2}{c}{$\begin{array}{c}\text { Beginning of } \\
1^{\text {st }} \text { year }\end{array}$} & \multicolumn{2}{c}{$\begin{array}{c}\text { Beginning of } \\
2^{\text {nd }} \text { year }\end{array}$} & \multicolumn{2}{c}{ End of 2 $2^{\text {nd }}$ year } & \\
\cline { 2 - 7 } 2016 & $M$ & $S D$ & $M$ & $S D$ & $M$ & $S D$ & $N$ \\
\hline & Recommendation & 2.73 & 1.00 & 2.49 & 1.06 & 2.77 & 1.01 & 70 \\
& Traditional & 2.78 & 1.17 & 2.70 & 1.22 & 2.91 & 1.16 & 91 \\
& Overall & 2.76 & 1.10 & 2.61 & 1.15 & 2.85 & 1.09 & 161 \\
& & & & & & & & \\
2017 & Recommendation & 2.73 & 1.07 & 2.64 & 1.04 & 2.84 & 0.99 & 70 \\
& Traditional & 2.66 & 1.08 & 2.61 & 1.20 & 2.79 & 1.22 & 97 \\
& Overall & 2.69 & 1.08 & 2.62 & 1.12 & 2.81 & 1.12 & 167 \\
\hline
\end{tabular}

\section{Discussion}

In terms of TOEIC scores, there are clear differences according to how students gained admission, with recommendation students generally scoring 70 to 80 points lower. This is consistent with previous research (Kochiyama, 2010), and indicates that examination type is a predictor of performance post-matriculation, so far as standardized academic tests are concerned. Students presently take the same curriculum, and traditional examination students may have a stronger base from which to start. Students who performed well on traditional examinations have spent a long time training for academic study. Since familiarity with strategies is associated with higher TOEIC scores (Nishitani, 2007), it is unsurprising that students who spent a significant amount of time at similar studies would perform better. Recommendation students may include students who performed poorly at the start and were encouraged to seek recommendations from their schools. Recommendation students probably do need special follow-up assistance post-matriculation, which might include thorough pre-matriculation study programs, separating classes by level, and offering English tutoring, none of which are systematically offered by Faculty Y.

However, how students gained admission does not appear to be a predictor of their attitudes towards English. Both traditional and recommendation examination students appear to not be satisfied prior to university, and many already do not like English but are somewhat neutral regarding looking forward to continuing their studies. Students also appear to experience a V-effect: They start off high, then drop, and slightly recover by the end of their 2nd year. Hesitancy towards English at the beginning of the 1st year was also observed in the free responses. Students frequently wrote comments such as kihon ga mattaku dekitenakute fuan ("I'm nervous because I don't have the basics at all") and yaru ki wa aru ga, nō ga oitsukanai ("I want to do it, but my brain can't catch up"). Yet some responses indicated that students did anticipate something different from university and wanted to use English actively, with comments such as English Speaking ga tanoshimi desu ("I'm looking forward to speaking English") and kaiwa ni chikara o irete hoshii ("I want [the university] to support conversation").

Although encouraging positive feelings towards English among students is a major challenge, the V-effect is likely indicative of an ineffective 1st-year curriculum. This suggests that Faculty $\mathrm{Y}$ is losing out on important opportunities to positively impact students' perceptions of English. Looking at the curriculum, Faculty Y's 1st-year classes focus largely on grammar, making them similar to high school classes. Indeed, the 2ndyear class focuses on conversation, which may account for why student evaluations of the courses improve after the 2 nd year.

\section{Conclusion}

The fact that how students have gained admission does not seem to be related to their attitudes towards English suggests that many students are receptive to effective curricula. Care should be taken to differentiate university classes from high school classes and create innovative curricula. Taking students' own perceptions of how English classes should be conducted into account so as to create more learner-centered curricula (see Holsworth, Usuki, \& Koshiba, 2016) may be one way to help improve student attitudes towards English study.

The issues noted here will become more pressing as the university admissions process evolves. Strict limits by the Ministry of Education on how much private universities can deviate from student quotas are pressuring universities to take in more recommendation students, as the recommendation examinations allow universities to control student numbers earlier, which can lead to traditional examinations becoming more competitive (Kobayashi, 2018). On the other hand, students' desire for stability-especially given major changes in entrance examinations pushed by the Ministry of Education-has led students who could perform well on traditional examinations to seek recommendations (Obunsha Education Center, 2019). These outside forces influencing how universities and students approach examinations could result in the gap between recommendation examination and the traditional examination students growing wider or changes in the profile of the "typical" recommendation student. 


\section{Bio Data}

Giancarla Unser-Schutz is an associate professor at Rissho University. She is currently interested in how to improve motivation and interest amongst students in non-EFL-specialist faculties. She also conducts research outside of EFL on the linguistic characteristics of manga as well as Japanese naming practices. Her publications may be found at http://rissho. academia.edu/GiancarlaUnserschutz/.<giancarlaunserschutz@ris.ac.jp>

\section{References}

Benesse Corporation. (2012, November 26). 大学生が振り返る大学受験調査一推薦・AO入学者の高 3 時の学習時間、「1日1時間未満」が半数 [Study on university students looking back at their entrance admission examinations: Majority of recommendation and AO examination students spent "1 hour a day" studying in their 3rd year of high school]. Benesse Corporation. Retrieved November 3, 2020, from https://berd.benesse.jp/berd/center/open/report/daigaku_jyuken/2012/pdf/ data_01.pdf

Higuchi, T. (2014). 今日の入学前教育推薦・A O 入試に伴う学習面の接続対策の実態と課題 [Prematriculation education today: The realities and problems of connection measures for learning with recommendation and AO examinations]. View2, 4(Winter), 20-23. Retrieved from https://berd.benesse.jp/up_images/magazine/VIEW21_dai_2014Winter-2.pdf

Holsworth, M., Usuki, T., \& Koshiba, K. (2016). Potential for changes: Learner-centered approaches to second language teaching in Japan. 京都産業大学論集 人文科学系列 [Kyoto Sangyo University Papers: Social Sciences and Humanities Fields], 49, 241-265. Retrieved from https://ksu.repo.nii. ac.jp/?action=repository_uri\&item_id=1442\&file_id=22\&file_no=1

Kobayashi, T. (2018). 私大の定員厳格化でAO・推薦枠が増えるカラクリ[Strict student numbers at private universities and the gimmick of $\mathrm{AO} / \mathrm{recommendation} \mathrm{placements].} \mathrm{AERA} \mathrm{Dot.} \mathrm{Retrieved}$ April 1, 2020, from https://dot.asahi.com/aera/2018103100007.html

Kochiyama, A. (2010). 新入生の英語能力と入試形態および動機づけに関する調査 [A study on the English ability of Wayo freshman: Focusing on their entrance exam type and motivation]. 和洋 女子大学紀要 [The Journal of Wayo Women's University], 50, 93-101. Retrieved from https://wayo. repo.nii.ac.jp/?action=repository_uri\&item_id=928\&file_id=22\&file_no=1

Metoki, M. (2014). T大学における入学形態と学生の英語力の関係 [The relationship between the types of university entrance examinations and Japanese students' English proficiency in T University]. 天使大学紀要 [Bulletin of Tenshi College], 14(2), 53-60. Retrieved from https://tenshi.repo.nii. ac.jp/?action=repository_uri\&item_id=254\&file_id=22\&file_no=1

Mori, R. (2002). Entrance examinations and remedial education in Japanese higher education. Higher Education, 43(1), 27-42. https://doi.org/10.1023/A:1012999527910
Munezane, Y. (2013). Ideal L2 self and valuing of Global English. In M. T. Apple, D. Da Silva, \&

T. Fellner (Eds.), Language learning motivation in Japan (pp. 152-169). Bristol, UK: Multilingual Matters. https://doi.org/10.21832/9781783090518-011

Nishitani, A. (2007). Is test preparation instruction effective in improving scores of the grammar section of the TOEIC? 京都産業大学論集. 人文科学系列 [Kyoto Sangyo University Papers: Social Sciences and Humanities Fields], 36, 93-104. Retrieved from https://ksu.repo.nii. ac.jp/?action=repository_uri\&item_id=1271\&file_id=22\&file_no=1

Obunsha Education Center. (2019). 大学入試 “超安全志向”の裹側で 指定校からの入学者が増 加! [University entrance examinations, on the backside of 'super stability-seeking mentality', an increase in students admitted through designated school recommendations!]. Obunsha. Retrieved December 31, 2019, from http://eic.obunsha.co.jp/resource/viewpoint-pdf/201912.pdf

Appendix

Tables

Table 9. Questions in the Original Japanese

\begin{tabular}{|c|c|c|}
\hline$\#$ & Question/statement & Answer form \\
\hline 1 & あなたは、海外に行ったことがありますか。 & ある/ない \\
\hline 2 & $\begin{array}{l}\text { あなたは、中学・高校での英語学習に真剣 } \\
\text { に取り組んできましたか。 }\end{array}$ & $\begin{array}{l}\text { A. 全くしなかった・B. あまりしなかっ } \\
\text { た・C. どちらでもない・D. 少しした・E. 非常 } \\
\text { によくした }\end{array}$ \\
\hline 3 & $\begin{array}{l}\text { あなたは、中学・高校での英語学習に満足 } \\
\text { しましたか。 }\end{array}$ & $\begin{array}{l}\text { A. 全くしなかった・B. あまりしなかつ } \\
\text { た・C. どちらでもない・D. 少し満足し } \\
\text { た·E. 非常に満足した }\end{array}$ \\
\hline 4 & $\begin{array}{l}\text { あなたは、大学で英語を勉強することを楽 } \\
\text { しみにしていますか。(○をひとつ) }\end{array}$ & $\begin{array}{l}\text { A. 全くしていない・B. あまりしていな } \\
\text { い·C. どちらでもない・D. 少ししてい } \\
\text { る・E. 非常にしている }\end{array}$ \\
\hline 5 & あなたは、英語を学ぶのが好きですか。 & $\begin{array}{l}\text { A. 全〈好きではない・B. あまり好きではな } \\
\text { い・C. どちらでもない・D. 少し好きだ・E. 非 } \\
\text { 常に好きだ }\end{array}$ \\
\hline
\end{tabular}


Unser-Schutz: What Do Entrance Examinations Say About EFL Outcomes at Universities?

\begin{tabular}{|c|c|c|}
\hline \# & Question/statement & Answer form \\
\hline 6 & 将来、海外留学をすることに関心がある。 & \multirow{6}{*}{$\begin{array}{l}1 \text { (全く当てはまらない)・2 (やや当てはま } \\
\text { らない)・3(やや当てはまる)・4 (当ては } \\
\text { まる) }\end{array}$} \\
\hline 7 & 将来、仕事で英語を使うことに関心がある。 & \\
\hline 8 & $\begin{array}{l}\text { 英語関連の資格試験(TOEIC/TOEFL、英検 } \\
\text { 等)の受験に関心がある。 }\end{array}$ & \\
\hline 9 & 外国の文化(映画や音楽等)に関心がある。 & \\
\hline 10 & 外国人と友だちになってみたい。 & \\
\hline 11 & 英語に関心がある。 & \\
\hline 12 & $\begin{array}{l}\text { その他に、英語教育に対する要望や英語学 } \\
\text { 習について伝えたいこがあった、教えて } \\
\text { ください。 }\end{array}$ & 自由記述 \\
\hline
\end{tabular}

Table 10. Results for Three-way ANOVA: Results of the TOEIC Examinations

\begin{tabular}{lrrrrc}
\hline Variable & \multicolumn{1}{c}{ SS } & df & \multicolumn{1}{c}{ MS } & F & $\boldsymbol{p}$ \\
\hline Class & $4,412.07$ & 1 & $4,412.07$ & 0.41 & ns \\
Examination type & $811,640.18$ & 1 & $811,640.18$ & 74.58 & $* *$ \\
Class x Examination type & $4,592.33$ & 1 & $4,592.33$ & 0.42 & ns \\
$\quad$ Error & $3,547,787.45$ & 326 & $10,882.78$ & & \\
\hline TOEIC scores & $5,242.38$ & 1 & $5,242.38$ & 1.93 & ns \\
Examination type x TOEIC scores & 946.21 & 1 & 946.21 & 0.35 & ns \\
Class x TOEIC scores & 496.82 & 1 & 496.82 & 0.18 & ns \\
Class x Examination type x TOEIC & $1,725.92$ & 1 & $1,725.92$ & 0.64 & ns \\
scores & & & & & \\
$\quad$ Error & $884,790.67$ & 326 & $2,714.08$ & & \\
\hline Total & $5,261,634.02$ & 659 & & & \\
\hline
\end{tabular}

Notes. $n s$ : Not significant, $* *:$ Significant at $1 \%$ level
Table 11. Results for Three-way ANOVA: Students' Self-Reported Intensity of Study

\begin{tabular}{|c|c|c|c|c|c|c|}
\hline Variables & & SS & df & MS & F & $p$ \\
\hline \multirow{10}{*}{ All variables } & Class & 1.88 & 1 & 1.88 & 1.21 & ns \\
\hline & Examination type & 0.31 & 1 & 0.31 & 0.20 & ns \\
\hline & Class $x$ Examination type & 4.73 & 1 & 4.73 & 3.04 & + \\
\hline & Error & 503.88 & 324 & 1.56 & & \\
\hline & Intensity of study & 59.10 & 2 & 29.55 & 37.39 & $* *$ \\
\hline & Examination type $\mathrm{x}$ Intensity of study & 4.77 & 2 & 2.38 & 3.02 & + \\
\hline & Class x Intensity of study & 3.82 & 2 & 1.91 & 2.42 & + \\
\hline & Class $\mathrm{x}$ Examination type $\mathrm{x}$ Intensity of study & 0.49 & 2 & 0.25 & 0.31 & ns \\
\hline & Error & 512.13 & 648 & 0.79 & & \\
\hline & Total & $1,091.10$ & 983 & & & \\
\hline \multirow{5}{*}{$\begin{array}{l}\text { Class } \mathrm{x} \\
\text { Examination } \\
\text { type }\end{array}$} & Class $\mathrm{x}$ Examination type (Traditional) & 6.29 & 1 & 6.29 & 7.96 & $* *$ \\
\hline & Class x Examination type (Recommended) & 0.32 & 1 & 0.32 & 0.41 & ns \\
\hline & Examination type x Class (2016) & 1.31 & 1 & 1.31 & 1.66 & ns \\
\hline & Examination type x Class (2017) & 3.73 & 1 & 3.73 & 4.72 & $*$ \\
\hline & Error & 503.88 & 324 & 0.79 & & \\
\hline \multirow{9}{*}{$\begin{array}{l}\text { Examination } \\
\text { type } \mathrm{x} \\
\text { Intensity of } \\
\text { study }\end{array}$} & $\begin{array}{l}\text { Examination type } \mathrm{x} \text { Intensity of study } \\
\text { (Start 1st year) }\end{array}$ & 0.08 & 1 & 0.08 & 0.08 & ns \\
\hline & Error (Intensity of study (Start 1st)) & 345.10 & 324 & 1.07 & & \\
\hline & $\begin{array}{l}\text { Examination type } \mathrm{x} \text { Intensity of study (End } \\
\text { 1st year) }\end{array}$ & 0.68 & 1 & 0.68 & 0.58 & ns \\
\hline & Error (Intensity of study (End 1st)) & 383.68 & 324 & 1.18 & & \\
\hline & $\begin{array}{l}\text { Examination type } x \text { Intensity of study (End } \\
\text { 2nd year) }\end{array}$ & 4.31 & 1 & 1.18 & 4.86 & $*$ \\
\hline & Error (Intensity of study (End 2nd)) & 287.23 & 324 & 1.18 & & \\
\hline & $\begin{array}{l}\text { Intensity of study x Examination type } \\
\text { (Traditional) }\end{array}$ & 16.06 & 2 & 1.18 & 10.16 & $* *$ \\
\hline & $\begin{array}{l}\text { Intensity of study } \mathrm{x} \text { Examination type } \\
\text { (Recommendation) }\end{array}$ & 47.81 & 2 & 1.18 & 30.25 & $* *$ \\
\hline & Error (Intensity of study) & 512.13 & 648 & 0.79 & & \\
\hline
\end{tabular}


Unser-Schutz: What Do Entrance Examinations Say About EFL Outcomes at Universities?

\begin{tabular}{lcrrccc}
\hline Variables & & SS & df & MS & F & $\boldsymbol{p}$ \\
\hline & Class x Intensity of study (Start 1st year) & 0.31 & 1 & 0.31 & 0.29 & ns \\
& Error (Intensity of study (Start 1st year)) & 345.10 & 324 & 1.07 & & \\
& Class x Intensity of study (End 1st year) & 0.21 & 1 & 0.21 & 0.17 & ns \\
Class x & Error (Intensity of study (End 1st year)) & 383.68 & 324 & 1.18 & & \\
Intensity of & Class x Intensity of study (End 2nd year) & 5.19 & 1 & 5.19 & 5.85 & $*$ \\
study & Error (Intensity of study (End 2nd year)) & 287.23 & 324 & 0.89 & & \\
& Intensity of study x Class (2016) & 46.35 & 2 & 23.18 & 29.32 & $* *$ \\
& Intensity of study x Class (2017): & 16.57 & 2 & 8.29 & 10.48 & $* *$ \\
& Error (Intensity of study) & 287.23 & 648 & 0.79 & & \\
\hline
\end{tabular}

Notes. $n s$ : Not significant, + : Significant at $10 \%$ level, * : Significant at $5 \%$ level, ** : Significant at $1 \%$ level
Table 12. Results for Three-way ANOVA: Students' Satisfaction With English Classes

\begin{tabular}{|c|c|c|c|c|c|c|}
\hline Variables & & SS & df & MS & $\mathbf{F}$ & $p$ \\
\hline \multirow{10}{*}{ All variables } & Class & 4.1219 & 1 & 4.1219 & 2.83 & + \\
\hline & Examination type & 0.3893 & 1 & 0.3893 & 0.27 & ns \\
\hline & Class $\mathrm{x}$ Examination type & 7.797 & 1 & 7.797 & 5.36 & $*$ \\
\hline & Error & 473.0284 & 325 & 1.4555 & & \\
\hline & Satisfaction & 254.7078 & 2 & 127.3539 & 154.28 & $* *$ \\
\hline & Examination type $\mathrm{x}$ Intensity of study & 0.2488 & 2 & 0.1244 & 0.15 & ns \\
\hline & Class x Intensity of study & 0.6803 & 2 & 0.3402 & 0.41 & ns \\
\hline & $\begin{array}{l}\text { Class } x \text { Examination type } x \text { Intensity of } \\
\text { study }\end{array}$ & 2.1255 & 2 & 1.0627 & 1.29 & ns \\
\hline & Error & 536.5667 & 650 & 0.8255 & & \\
\hline & Total & $1,279.67$ & 986 & & & \\
\hline \multirow{5}{*}{$\begin{array}{l}\text { Class } \mathrm{x} \\
\text { Examination } \\
\text { type }\end{array}$} & Class x Examination type (Traditional) & 11.6285 & 1 & 11.6285 & 14.09 & $* *$ \\
\hline & $\begin{array}{l}\text { Class x Examination type } \\
\text { (Recommended) }\end{array}$ & 0.2904 & 1 & 0.2904 & 0.35 & ns \\
\hline & Examination type x Class (2016) & 2.3509 & 1 & 2.3509 & 2.85 & + \\
\hline & Examination type x Class (2017) & 5.8353 & 1 & 5.8353 & 7.07 & $* *$ \\
\hline & Error & 473.0284 & 325 & 0.8255 & & \\
\hline
\end{tabular}

Notes. $n s$ : Not significant, + : Significant at $10 \%$ level, * : Significant at $5 \%$ level, ** : Significant at $1 \%$ level 
Unser-Schutz: What Do Entrance Examinations Say About EFL Outcomes at Universities?

Table 13. Results for Three-way ANOVA: Degree Students Looked Forward to Studying English

\begin{tabular}{|c|c|c|c|c|c|c|}
\hline Variables & & SS & df & MS & $\mathbf{F}$ & $p$ \\
\hline \multirow{10}{*}{ All variables } & Class & 1.4214 & 1 & 1.4214 & 0.58 & ns \\
\hline & Examination type & 0.0011 & 1 & 0.0011 & 0 & ns \\
\hline & Class x Examination type & 1.7048 & 1 & 1.7048 & 0.7 & ns \\
\hline & Error & 787.3662 & 324 & 2.4301 & & \\
\hline & Looking forward & 17.2196 & 2 & 8.6098 & 12.64 & $* *$ \\
\hline & Examination type $\mathrm{x}$ Looking forward & 0.0343 & 2 & 0.0172 & 0.03 & ns \\
\hline & Class x Looking forward & 3.2257 & 2 & 1.6128 & 2.37 & + \\
\hline & $\begin{array}{l}\text { Class } \mathrm{x} \text { Examination type } \mathrm{x} \text { Looking } \\
\text { forward }\end{array}$ & 0.3389 & 2 & 0.1695 & 0.25 & ns \\
\hline & Error & 441.4302 & 648 & 0.6812 & & \\
\hline & Total & $1,252.74$ & 983 & & & \\
\hline \multirow{2}{*}{$\begin{array}{l}\text { Examination } \\
\text { type } \mathrm{x}\end{array}$} & $\begin{array}{l}\text { Examination type } \mathrm{x} \text { Looking forward } \\
\text { (Start 1st year) }\end{array}$ & 0.6051 & 1 & 0.6051 & 0.46 & ns \\
\hline & Error (Looking forward (Start 1st)) & 424.2384 & 324 & 1.3094 & & \\
\hline \multirow{7}{*}{$\begin{array}{l}\text { Looking } \\
\text { forward }\end{array}$} & $\begin{array}{l}\text { Examination type } \mathrm{x} \text { Looking forward } \\
\text { (End 1st year) }\end{array}$ & 2.0824 & 1 & 2.0824 & 1.61 & ns \\
\hline & Error (Looking forward (End 1st)) & 420.1128 & 324 & 1.2966 & & \\
\hline & $\begin{array}{l}\text { Examination type } \mathrm{x} \text { Looking forward } \\
\text { (End 2nd year) }\end{array}$ & 1.9595 & 1 & 1.9595 & 1.65 & ns \\
\hline & Error (Looking forward (End 2nd)) & 384.4453 & 324 & 1.1866 & & \\
\hline & $\begin{array}{l}\text { Looking forward x Examination type } \\
\text { (Traditional) }\end{array}$ & 2.8945 & 2 & 1.4473 & 2.12 & ns \\
\hline & $\begin{array}{l}\text { Looking forward } \mathrm{x} \text { Examination type } \\
\text { (Recommendation) }\end{array}$ & 17.5507 & 2 & 8.7754 & 12.88 & $* *$ \\
\hline & Error (Looking forward) & 384.4453 & 648 & 0.6812 & & \\
\hline
\end{tabular}

Notes. $n s$ : Not significant, + : Significant at $10 \%$ level, **: Significant at $1 \%$ level
Table 14. Results for Three-way ANOVA: Degree Students Like Learning English

\begin{tabular}{llrrrrr}
\hline Variables & SS & df & MS & F & $\boldsymbol{p}$ \\
\hline \multirow{4}{*}{ Class } & 0.0739 & 1 & 0.0739 & 0.03 & ns \\
& Examination type & 0.4431 & 1 & 0.4431 & 0.15 & ns \\
& Class x Examination type & 2.1135 & 1 & 2.1135 & 0.73 & ns \\
\cline { 2 - 7 } variables & Error & 933.3862 & 324 & 2.8808 & & \\
\cline { 2 - 7 } & Like learning English & 7.7694 & 2 & 3.8847 & 8.99 & $* *$ \\
& Examination type x Like learning English & 0.4025 & 2 & 0.2012 & 0.47 & ns \\
& Class x Like learning English & 0.3382 & 2 & 0.1691 & 0.39 & ns \\
& Class x Examination type x Like learning & 0.1742 & 2 & 0.0871 & 0.2 & ns \\
& English & & & & & \\
& Error & 280.124 & 648 & 0.4323 & & \\
\cline { 2 - 7 } & Total & $1,224.82$ & 983 & & & \\
\hline
\end{tabular}

Notes. $n s$ : Not significant, $* *$ : Significant at $1 \%$ level 